desde la academia | dossier

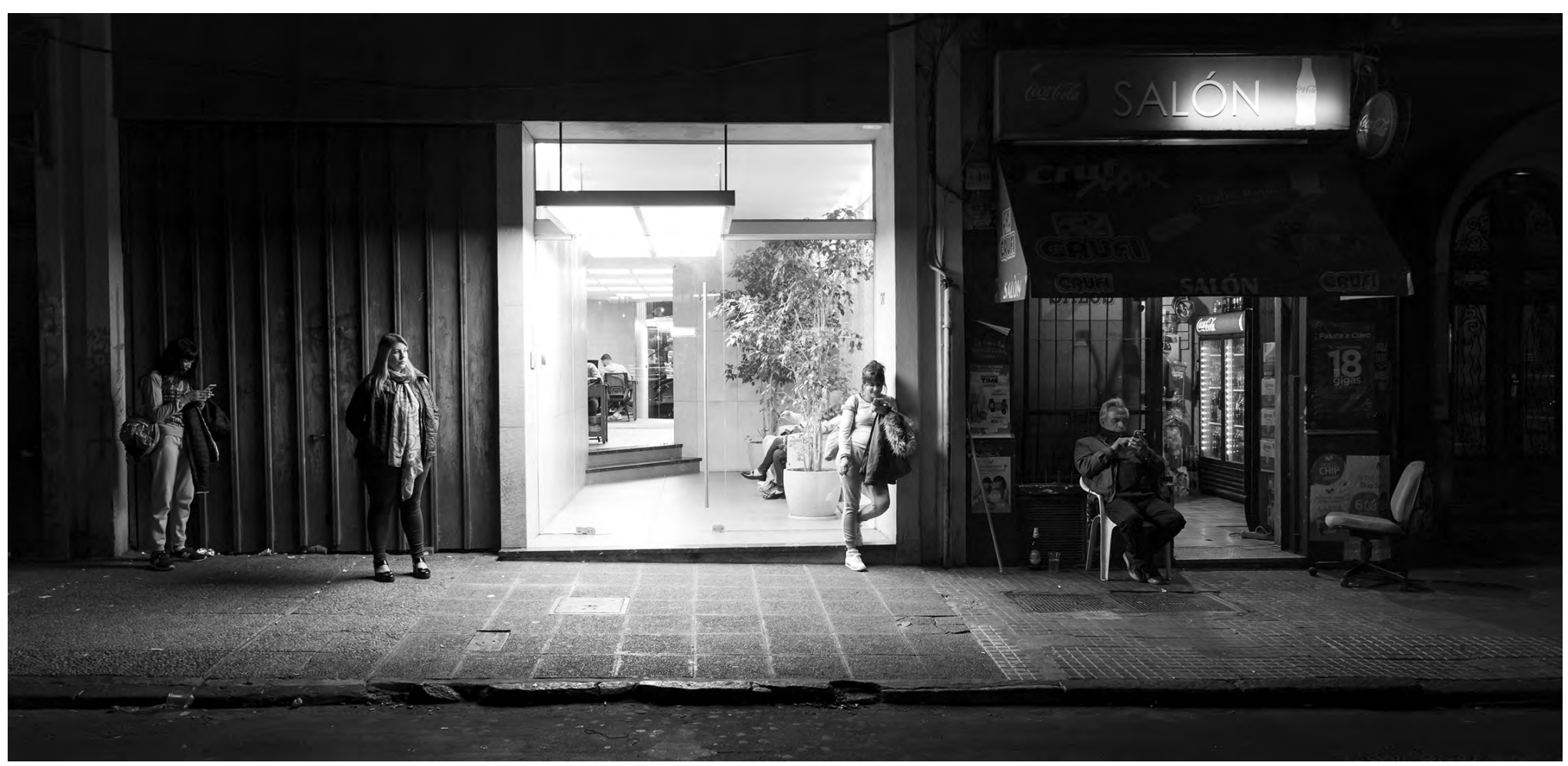

Foto: Ignacio Sánchez

\title{
El camino de Sísifo y la nostalgia reflexiva en el cine de Juan José Campanella
}

The path of Sisyphus and the reflective nostalgia in the cinema of Juan José Campanella

DOI: https://doi.org/10.22235/d.v0i31.1820

Hugo Hortiguera 


\section{RESUMEN}

Tomando como referencia herramientas de la geografía crítica, los estudios culturales, de política y de urbanismo, este artículo propone explorar la cuestión de los espacios urbanos representados en dos productos fílmicos de Juan José Campanella: Luna de Avellaneda (2004) y Metegol (2013). Se presta especial atención al contexto de producción de las películas y se analizan también la recurrencia de ciertas "ficciones orientadoras" (Shumway, 1993), la construcción de sus límites imaginarios y las relaciones que los personajes tienen con ellos. Se concluye que ambas películas proyectan reconstrucciones simbólicas de larga data sobre su sociedad, al tiempo que exhiben sus luchas irresueltas y debaten un sentido de pertenencia comunitario.

Palabras clave: eterno retorno; comunidad; forma espacial; topografía urbana; nostalgia reflexiva.

\section{Introducción}

Nunca podremos volver a la escena primaria de nuestros inicios y sus prístinos "orígenes". (lain Chambers, 1994, p. 103) $^{1}$

Una de las críticas más frecuentes que se ha hecho del cine de Juan José Campanella es su recurrencia a una manipulación sentimental kitsch que, según algunos estudiosos, apunta a promover un tipo de emoción nostálgica y reaccionaria, atravesada por "lugares comunes que neutralizan la inteligencia y capacidad crítica de su audiencia" (Koza, 2004, p. 76). Otros, en cambio, perciben esa misma nostalgia con un valor positivo y en ella creen ver que "la persistencia del pasado no constituye una fantasía regresiva, sino una potencialidad" (Dillon, 2015, p. 26).

\section{ABSTRACT}

With an approach to critical geography, cultural studies, politics and urbanism, this article proposes to explore the question of urban spaces represented in two films directed by Juan José Campanella: Luna de Avellaneda [Moon of Avellaneda] (2004) and Metegol [Underdogs] (2013). Consideration is paid to the films' production context and their consumption, the recurrence of certain "guiding fictions" (Shumway, 1993), the construction of their imaginary limits, and the relationships that the characters have with them. It concludes that both films project long-standing symbolic reconstructions of their society, while exhibiting its unresolved struggles and debating a sense of community belonging.

Keywords: eternal return; community; spatial form; urban topography; reflective nostalgia.
Hugo Hortiguera

Griffith University, Brisbane, Australia. https://orcid.org/00000001-6689-528X h.hortiguera@griffith.edu.au

Recepción: 08/05/2019 Aceptación: 12/09/2019
Partiendo de esta controversia, este artículo se propone analizar la "forma espacial" del cine de Campanella y su relación con el uso ideológico de la nostalgia. ${ }^{2}$ Para esto, se tomarán como ejemplos dos películas que han sido consideradas por el propio director como dos versiones de una misma historia: Luna de Avellaneda (de 2004) y Metegol (de 2013). En mi argumentación, partiré del mito de Sísifo para analizar cómo ciertos elementos de esta historia (la repetición infınita como castigo inútil y sin esperanza) serán usados por este director -tanto en el nivel de la historia como en el del discurso- con un valor didáctico, con el fin de exhibir ciertos principios que guían la existencia de su comunidad, sus problemas recurrentes y sus conflictos irresueltos. Luego de una breve contextualización
1:: Traducción propia.

2:: Por "forma espacial" (término acuñado por Joseph Frank) entenderé aquí no solo un aspecto literal, que apunta al espacio representado en sí, sino también al principio que rige el orden del filme, esto es, los esquemas fundamentales que se encuentran detrás del mundo ficticio. Para más detalles sobre este punto, véanse Joseph Frank (1991) y W.J.T. Mitchell (1980). 
histórica, se analizará la representación que estos dos filmes hacen de su ámbito comunitario, atravesado por un sentimiento iterativo de nostalgia que, en manos de Campanella, se convertirá en el detonante de un modo de reflexión cinematográfica sobre su sociedad que atraviesa toda su filmografía.

Sísifo y el eterno retorno

"Los mitos", nos dice Zygmunt Bauman (2008, p. 2), “no relatan historias para divertir". Están pensados para enseñar, para repetir sin cesar un tipo de mensaje que la audiencia debe aprender y asimilar, "y solo puede olvidar o descuidar bajo su responsabilidad". Para Albert Camus (1995, p. 159), en tanto, "los mitos están hechos para que la imaginación los anime”.

En este sentido, el caso del mito de Sísifo se presenta muchas veces como metáfora del esfuerzo inútil e incesante del hombre. Aunque el motivo del castigo al que fue sometido no es mencionado por Homero en el Libro XI de La Odisea, su historia es bien conocida y se ha reconstruido a partir de otros textos (véase Graves, 1985). Habiendo sido condenado por Zeus - por haber revelado secretos divinos- y por los jueces de los Muertos - por haber engañado a Hades y Perséfone-, Sísifo había sufrido un castigo implacable: empujar sin cesar una roca hasta la cumbre de una montaña. Una vez que llegaba con ella hasta allí, la piedra volvía a caer por su propio peso y él se veía obligado a retroceder para reanudar su tarea eternamente.

Que este mito sea trágico, continúa Camus (1995, p. 162), se debe a que el héroe tiene conciencia de su condición miserable en ese preciso momento en que regresa a la falda de la montaña para recoger la piedra una vez más. Mientras desciende por ese espacio que separa la cumbre de la roca piensa en su situación. Su tragedia comienza en el instante en que atraviesa esa geografía y sabe y reconoce que su destino solo le pertenece a él:
Por lo demás, sabe que es dueño de sus días. En ese instante sutil en que el hombre vuelve sobre su vida, como Sísifo vuelve hacia su roca, en ese ligero giro, contempla esa serie de actos desvinculados que se convierte en su destino, creado por él, unido bajo la mirada de su memoria y pronto sellado por su muerte. Así, persuadido del origen enteramente humano de todo lo que es humano, ciego que desea ver y que sabe que la noche no tiene fin, está siempre en marcha. La roca sigue rodando (Camus, 1995, p. 162).

Ese espacio que atraviesa en el regreso, así descrito, se convierte en el ámbito del reconocimiento, en el lugar en donde registra sus propias limitaciones y grandezas. Detrás de esta descripción de personajes, lugares y acciones se encuentra, entonces, todo un entramado de simbolismo complejo. Analizar ese ámbito y ese momento es de vital importancia para comprender en forma completa esa anagnórisis por la que pasa el sujeto de nuestro mito.

Georges Balandier (1994, pp. 15-16), por su parte, citando los trabajos de Nicolai Evreinov, observa que, cualquiera sea la forma que una sociedad adopta para organizar y representar su estructura de poder, se podrá encontrar en ella -como en sordina- la influencia de las artes escénicas. En el caso de la cultura griega clásica, estas están detrás de cada una de las manifestaciones de la existencia social. Esta "teatrocracia" que gobernaba la vida cotidiana ponía en escena los juegos que tejían su entramado comunitario. Es así que, prosigue, los grandes mitos representados en el teatro de las antiguas ciudades griegas servían para encarnar los principios que regían la vida de la sociedad, junto con sus problemas y conflictos. Si la verdad del poder se ocultaba bajo los ropajes de las grandes mitologías, continúa, se podría deducir entonces que el imaginario explicaba 
el fenómeno político. “Todo sistema de poder es un dispositivo destinado a producir efectos, entre ellos los comparables a las ilusiones que suscita la tramoya teatral" (Balandier, 1994, p. 16).

En nuestra contemporaneidad, sin embargo, aquellos mitos de los que nos hablaban Bauman, Camus o Balandier, y que permitían tomar conciencia de la propia existencia comunitaria, han ido dando paso a otras formas de relatos. Estos quizás se manifiestan hoy de manera relevante en la cultura audiovisual. En ella, la ficción cinematográfica cumple un papel notable, dadas "las operaciones de reconceptualización y metaforización que realiza en conexión con otros campos de la vida social" (García Canclini, 2011, p. 74). La propia Hannah Arendt (1998, p. 211) ha señalado, por su lado, que es a través del arte en general, y de las artes escénicas en particular, que se traspone "la esfera política de la vida humana", por cuanto su tema es el ser humano en su relación con los demás. Y aunque ella se refiere en particular al teatro, yo me permitiría añadir aquí la narración cinematográfica.

En esta misma línea de pensamiento, parece coincidir Gustavo Aprea (2008, p. 10). En efecto, para él, la tarea que cumple el cine en la comprensión de un determinado período histórico y su problemática es significativa para la vida contemporánea de una sociedad, por cuanto en su producción se desarrolla y filtra una parte importante de su cultura política y de cómo piensa su propio lugar. Si los filmes son - como lo era el teatro en la antigua Grecia- un lugar privilegiado de reflexión sobre la vida social de una comunidad, es porque en su puesta en escena se debaten y confrontan sus representaciones sociales y se construyen sus memorias y sus identidades colectivas. Es a partir de las historias que se narran y de las imágenes que se hacen circular entre sus miembros que se funda un espacio simbólico compartido de reflexión sobre lo que significa formar parte de una comunidad. ${ }^{3} \mathrm{Y}$ "comunidad" es, en palabras de Anthony Cohen (2001):

esa entidad a la que uno pertenece, mayor que la afinidad, pero más inmediata que la abstracción que llamamos "sociedad". Es el ámbito en el que las personas adquieren su experiencia más fundamental y sustancial de la vida social fuera de los confines del hogar. En ella aprenden el significado de la afinidad al poder percibir sus límites - esto es, al yuxtaponerlo a la no afinidad; aprenden la "amistad"; adquieren los sentimientos de una estrecha asociación social y la capacidad de expresarlos o gestionarlos de otra manera en sus relaciones sociales. La comunidad, por lo tanto, es donde uno aprende y continúa practicando cómo "ser social” (p. 15). ${ }^{4}$

En este sentido, en la narración cinematográfica una comunidad puede reconocer y entender el significado de las acciones llevadas a cabo por sus integrantes en el espacio común y encauzarlo dentro del marco simbólico que conforman los relatos de la nación. En consecuencia, a través de este tipo de historias podría resultar significativo analizar la forma en que ciertos símbolos son utilizados para delimitar el espacio común y revalidarlo cuando ciertos procesos o cambios amenazan su integridad.

En efecto, el espacio cinematográfico que se pone en pantalla nos permitiría reflexionar sobre los territorios comunitarios y sobre las relaciones e identidades que se establecen en ellos. Volviendo a Camus, serviría como un instrumento de comprensión e interpretación de ciertos momentos particulares que se desarrollan en esos ámbitos de convivencia, apelando a una búsqueda de un sentido y a la vez de reafirmación de una serie de comportamientos o
3:: Extenderme en un panorama teórico sobre la cuestión de la comunidad y sus múltiples perspectivas excedería el objetivo de este artículo. Al lector interesado le recomiendo, además del trabajo de Cohen, consultar a Benedict Anderson (2007), Zygmunt Bauman (2001, 2004, 2008, 2009), Nicolas Shumway (1993), Jacques Rancière (2007), Duncan Bell (2003) y Richard Sennett (1978 y 2012), entre otros.

4:: Traducción propia. 
5:: Traducción propia N. de T: Juego de palabras del original entre los términos real-life y reel-life.

6:: Gran parte de la crítica ha destacado que Luna de Avellaneda retrata el fracaso del proyecto neoliberal impulsado por la administración de presidente Menem en la década del noventa y sus efectos políticos, sociales y culturales (véanse Capano, 2017; Schmidt, 2012: Andermann

2015; Dillon, 2015, entre otros). Sin embargo, a mi juicio, estas afirmaciones pierden de vista que, además de esto, la película está anticipando, casi inconscientemente, el ascenso incipiente del

kirchnerismo unos meses más tarde. Volveré sobre esto más adelante. conductas que hacen a la supervivencia social. De esta manera, todo lo que se dice, lo que se calla, lo que se exhibe y lo que se esconde en las historias que el cine cuenta y en las imágenes que muestra sobre su espacio nacional adquiere una relevancia fundamental para comprender la manera en que sectores de esa colectividad se ven e interpretan a sí mismos en un determinado momento histórico. La forma espacial en la narrativa cinematográfica, en este sentido, no puede dejarse de lado. A fin de cuentas:

La forma en que los espacios son usados y representados en el cine refleja las normas culturales, las costumbres éticas, las estructuras sociales y las ideologías imperantes. Al mismo tiempo, el impacto de una película en una audiencia puede moldear experiencias sociales, culturales y ambientales. Es evidente que una línea de investigación centrada en la producción y el consumo del espacio y del lugar en el cine merece una seria atención geográfica. Si nosotros, como geógrafos, estamos de acuerdo con muchos de los comentaristas sobre la condición postmoderna que ven poca diferencia entre nuestra cultura política y nuestra cultura del celuloide, entre la vida real y la vida del carrete, ${ }^{5}$ entonces la representación cinematográfica debe ser una parte clave de la investigación geográfica (Aitken y Zonn, 1994, p. 5).

¿Cuál es, entonces, la relación que se establece entre los miembros de una comunidad, sus actos y su geografía? ¿Cómo se recorre y cuáles son los peligros que amenazan fragmentar esa topografía en la ficción? ¿Cómo se escenifican en esos espacios -algunas veces ruinosos- los dramas que se cruzan en ella? En pocas palabras, ¿cómo son los modos de autorreflexión cinematográfica? Tomando como referencia herramientas de la geografía crítica, los estudios culturales, de política y de urbanismo -entre otros-, en las páginas siguientes se prestará especial atención al contexto de producción de ambos filmes, teniendo en cuenta que estos se estrenaron en dos momentos históricos claves de la Argentina del nuevo siglo: el ascenso del kirchnerismo (2003-2007) y la cercanía de su final (2011-2015). ${ }^{6}$ Así, se partirá del concepto de "ficciones orientadoras" (Shumway, 1993), que abreva en el trabajo seminal de Benedict Anderson (2007), y se analizarán la construcción imaginaria de esos "espacios de convivencia" que mencionaba más arriba y las relaciones que los personajes tienen con ellos.

\section{Contexto histórico}

Hacia finales de 2001, el nuevo gobierno del presidente Fernando De la Rúa, que había sucedido a la administración neoliberal de Carlos Menem (1989-1995/1995-1999) en 1999, se encontró con la imposibilidad de pagar los préstamos del Fondo Monetario Internacional y de otros organismos internacionales de crédito. El nuevo presidente se vio obligado a dimitir, en medio de una violencia sin precedentes. Como el vicepresidente había renunciado unos meses antes de la dimisión de De la Rúa, el Congreso fue convocado para nombrar a un nuevo mandatario. Tras un período tumultuoso en el que se sucedieron tres presidentes provisionales en pocos días, el parlamento eligió al senador Eduardo Duhalde para cubrir interinamente las funciones del ejecutivo. Este logró mantenerse en el poder por más tiempo (enero de 2002 - mayo de 2003), encaminar la grave crisis financiera y convocar a elecciones presidenciales. 


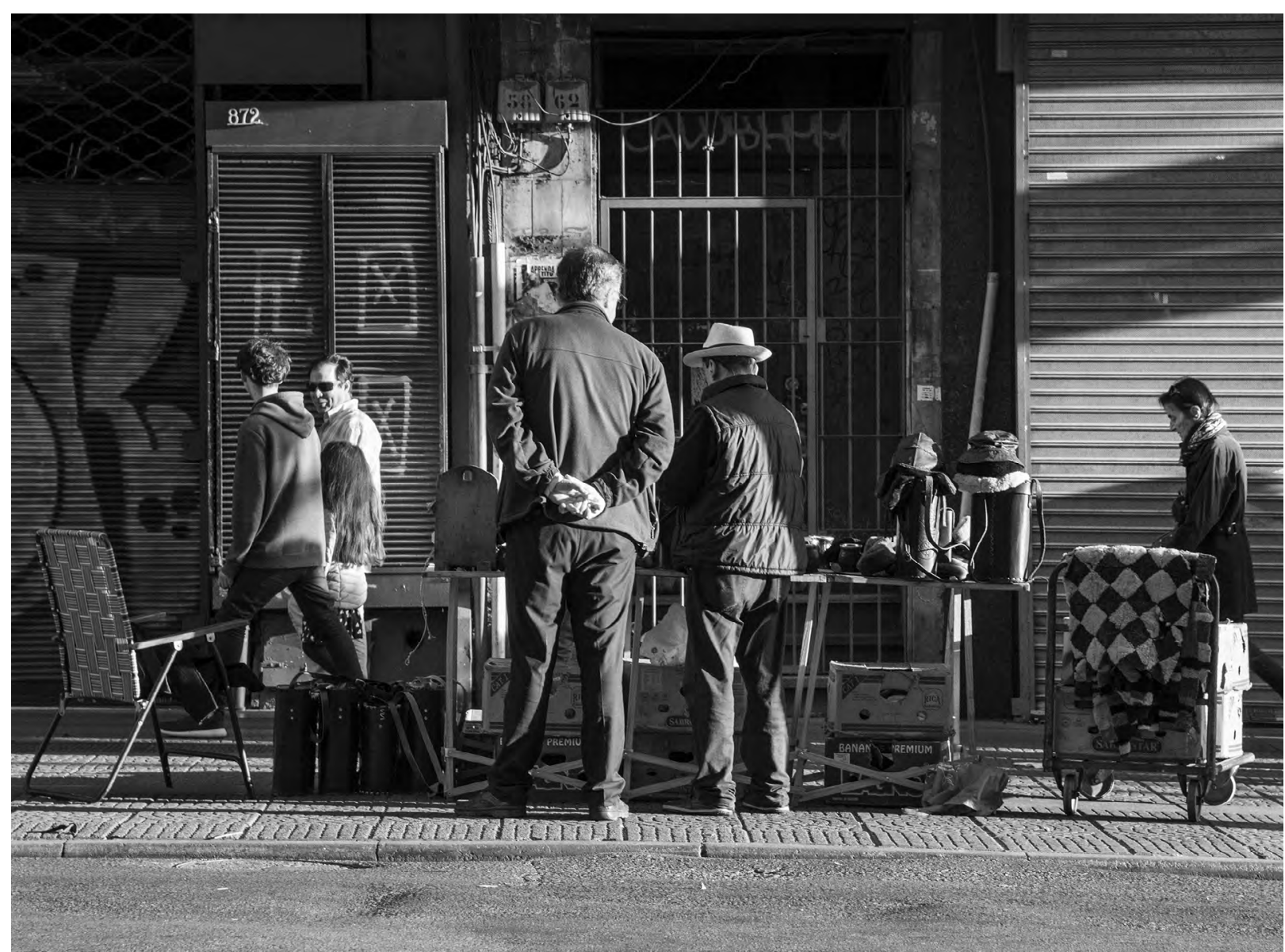

Foto: Ignacio Sánchez

En 2003, Néstor Kirchner, un desconocido gobernador peronista de la lejana provincia sureña de Santa Cruz, era elegido presidente para el período 2003-2007, con apenas el 22 por ciento del electorado. ${ }^{7} \mathrm{Al}$ finalizar su primer término, el presidente Kirchner no se presentó para su reelección, sino que propuso a su esposa, Cristina Fernández de Kirchner (2007-2011), para el cargo de presidenta. La estrategia que se buscaba era osada, astuta, pero simple: la alternancia de ambos en el poder -algo no contemplado en la constituciónpermitiría a la pareja matrimonial mantenerse al frente del ejecutivo por un período más extenso. Sin embargo, la maniobra de Kirchner se frustró cuando el 27 de octubre de 2010 moría en su casa de El Calafate, después de sufrir un ataque al corazón. Su viuda fue reelecta en 2011, y ejerció el cargo hasta 2015, año en que asumió Mauricio Macri. El proyecto de la alternancia familiar indefinida en el poder había concluido.

Las dos administraciones de Cristina Kirchner no trascurrieron sin controversias. Las acusaciones de corrupción, nepotismo y hasta de violencia política se sucedieron con reiterada frecuencia a lo largo de sus ocho años al frente del gobierno. Lo cierto es que, en esos casi doce años en que los Kirchner manejaron los destinos del país de una $\mathrm{u}$ otra forma, se fue construyendo, paulatinamente, lo que Ana Soledad Montero (2007a, p. 319) dio en llamar un "ethos discursivo militante”, informal, juvenil, transgresor y, sobre todo, combativo. Gracias a esta estrategia, Néstor Kirchner y su viuda se mostraron como continuadores de una militancia peronista setentista que volvía, a través de ellos, a resituar la lucha por la verdad, la memoria y la justicia en el país después de casi treinta años de gobiernos democráticos. Se evocaba nostálgicamente la idea de un pasado puro y perdido que la pareja había decidido recuperar para enfrentarlo a un presente contaminado. ${ }^{8}$

Mucho se ha hablado - con mayor o menor suerte- de la permanente conexión que los Kirchner explotaron con esa militancia, construyendo un arco ideológico cruzado por la nostalgia que restauraba "en forma casi heroica aquello que consideraban había estado au-
7:: En la primera vuelta electoral de 2003, quedaron enfrentados Carlos Menem, presidente entre 1989 y 1999, y Néstor Kirchner, por el Frente para la Victoria. Menem había ganado con el $24 \%$ de los votos y con solo el $2 \%$ por delante de Kirchner. Para la segunda vuelta, las encuestas pronosticaban a Kirchner como ganador. Ante una inminente derrota, Menem decidió retirarse especulando acaso con que la poca base con la que Kirchner llegaba al poder haría su gobierno insostenible.

8:: Para una introducción al planteo inicial del programa de gobierno de Néstor Kirchner y los relatos que este intentó hacer circular tempranamente (algo que, por problemas de espacio, me resulta imposible detallar aqui), puede verse Fernández Pedemonte, 2006. Es interesante destacar esta apelación a una "nostalgia restaurativa" (la expresión pertenece a Boym, 2001), que intentaba resituar en el escenario político un conjunto de asuntos culturales o sociales olvidados o derrotados, dejando de lado sus elementos conflictivos. Retomaré este punto. 
9:: La bibliografia en este punto es extensa, pero no me detendré aqui en ello. Remito al lector interesado

a unos pocos ejemplos que podrán ayudarle a comprender este periodo con más detalle (Montero, 2007, 2008, 2009a, 2009b; Montero y Vincent 2013; Altamirano, 2007; Barbosa, 2010; Sarlo, 2011; Andriotti Romanin, 2011; Korstanje, 2011).

10:: Jorge Lanata tiene una presencia importante en el espectro mediático argentino y se lo podría considerar un formador de opinión relevante en radio (Radio Mitre) y televisión (Canal 13). Cuenta, además, con una columna semanal en un periódico de gran tirada los domingos (Clarín). Todos los medios pertenecen al mismo conglomerado (el Grupo Clarín), que estuvo enfrentado al kirchnerismo durante su administración. sente y faltante en la Argentina democrática" (Daín y Barros, 2011, p. 5). ${ }^{9}$ La estrategia seguida por los Kirchner me interesa en parte porque algunos analistas políticos y sociales argentinos han destacado, durante esos doce años de gobierno kirchnerista, la existencia de una división cultural irreconciliable en el país, bautizada como "la grieta". Uno de los primeros en introducir el término para referirse a este concepto fue el periodista Jorge Lanata, quien hacia agosto de 2013 explicaba:

[En la actualidad] hay como una división irreconciliable en la Argentina que yo llamo "la grieta”. Creo que la grieta es lo peor que nos pasa. Incluso va a trascender al actual gobierno..., y... va a permanecer. La grieta no es política; es cultural, en el sentido extenso. Tiene que ver con cómo vemos el mundo.... Creo que todos somos la patria y el país. Nadie tiene el copyright de la patria. La Argentina no es una marca registrada de nadie, de ningún partido, de ningún movimiento, de ningún gobierno. Nadie tiene el copyright de la verdad. Ojalá que alguna vez podamos superar esta grieta porque dos medias Argentinas no suman una Argentina. Dos medias Argentinas son dos medias Argentinas. No suman una Argentina entera (Telefé, 2013).

Las palabras de Lanata, un periodista altamente crítico del gobierno de los Kirchner, inauguraron un debate que todavía continúa. ${ }^{10}$ Desde entonces, el concepto se reinstaló en el espacio argentino y se propagó a muchísimos otros programas de radio y televisión y a una gran cantidad de artículos periodísticos y análisis políticos. La fractura de la sociedad argentina se había convertido en tema de debate.

En realidad, la noción no era original, pero sí retomaba, de manera sencilla, una divisoria omnipresente a lo largo de la historia política argentina. De esta forma lo destacaron algunos críticos del periodista, quienes de inmediato salieron a cuestionar sus dichos, argumentando que semejante división estaba instalada en esa geografía desde la llegada de los primeros europeos al Río de la Plata (Domínguez, 2013). Si esto era así, se alegaba, la mentada "grieta" nada tenía que ver con un supuesto armado cultural del kirchnerismo. Por el contrario, este no habría instituido ese espacio de disputa, sino que se trataría de una cosmovisión cultural mucho más arraigada en su historia. En efecto, en esto parecían coincidir con Nicolas Shumway (1993, p. 12), para quien esta cosmovisión antinómica es una "peculiar mentalidad divisoria creada por los intelectuales del país en el siglo XIX, en la que se enmarcó la primera idea de la Argentina”.

De acuerdo con Shumway (1993, p. 13), al fundarse una nación se inventa un repertorio o paradigma de temas y una retórica que contribuye a constituir la identidad del país. Estas "ficciones orientadoras", como él las llama, son creaciones discursivas que les dan a los ciudadanos un sentimiento de identidad colectiva y un destino común nacional. En la práctica, no pueden ser probadas, y en los hechos, son tan artificiales como cualquier ficción literaria. Una de las ficciones argentinas más comunes podría representarse por el "mito de la exclusión", que inauguraría toda una serie antinómica de pensamiento: civilización y barbarie, unitarios y federales, peronistas y antiperonistas, militares y civiles.

Otra estaría dada por la idea de grandeza a la que estaría predestinada la nación argentina desde sus origenes y que generará toda una serie de declaraciones rimbombantes e hiperbólicas de muchos políticos (el famoso "destino de grandeza de la nación argentina", utilizada por el General Perón en muchas de sus alocuciones o, más recientemente, aquellas palabras del 
presidente interino Eduardo Duhalde sobre el hecho de que "los argentinos estaban condenados al éxito", durante los primeros meses del 2002 para transmitirle al pueblo su optimismo en las negociaciones con el Fondo Monetario Internacional).

Una tercera ficción, conectada a la anterior y que buscaría explicar las causas del fracaso argentino, podría entenderse como la visión de la grandeza argentina frustrada por enemigos internos (ver Scheines, 1992; Pasquini Durán, 1995; Feinmann, 1998). Siguiendo ese razonamiento, se podría deducir que el matrimonio Kirchner y sus partidarios no habrían hecho más que retomar ese giro emotivo -ya presente en la historia del pensamiento argentino-y enfatizarlo en el espacio público para su propio provecho. ${ }^{11}$

Se podría criticar en este punto, citando un supuesto anacronismo teórico, que el concepto de "ficciones orientadoras" remite solo a aquellas producciones culturales que buscaron una construcción identitaria nacional en los origenes del estado-nación. No obstante, el propio Shumway, ejemplificando con el caso del peronismo, señala esto como una crítica injusta habida cuenta de que esto es lo que ha hecho el peronismo desde sus orígenes: reformular y reciclar los paradigmas retóricos del siglo XIX durante todo el siglo XX y parte del siglo XXI (para una interesante discusión sobre este hecho remito a la entrevista de Neyret, 2004).

En este punto, parece coincidir Alejandro Katz (2013), quien ha observado que las visiones del futuro argentino se construyen una y otra vez a partir de imágenes arcaicas:

Para algunos, el mejor futuro es el del país agrario, de finales del siglo XIX; para otros, el país peronista de la justicia social de 1945; algunos más miran a la Argentina de 1973 y sus ilusiones vagamente revolucionarias y confusamente socialistas; ya hay quienes, incluso, tienen en la década de 1990 el modelo de país al que querrían regresar, y muchos desean que el presente se perpetúe en un futuro que será entonces, también, una imagen del pasado. La prolongada queja por la ausencia de aquello que algunos llaman "proyecto nacional” la emiten lastimosamente los mismos que piensan que un "proyecto nacional" consiste en que el país sea algo parecido a lo que alguna vez ya fue (p. 14).

Es verdad, sin duda, que, desde la publicación del Facundo de Sarmiento hasta la fecha, esta matriz dicotómica ha sido una lectura reiterada de la cultura argentina como forma de explicar no solo procesos históricos y culturales, sino también la producción de discursos artísticos (Lusnich, 2005, p. 13). El caso de la cinematografía en particular es un ejemplo de ello, por cuanto sus relatos se han apropiado, en palabras de Lusnich (2005, p. 16), de los términos de esa dicotomía sarmientina y generado diferentes núcleos de acceso y de lectura de esos enunciados opuestos.

Muchos cineastas (como Pablo Trapero, Adrián Caetano o Marcelo Piñeyro, entre otros) han exhibido en las narraciones fílmicas de esos años espacios fragmentados y derruidos de la ciudad, a la vez que han aludido a los ámbitos que habría que rehacer o reinventar para reconstruir un lugar de encuentro hoy en profunda disputa. En sus relatos parecen haberse hecho eco de esta interpretación divisoria de la sociedad de la que hablaba más arriba, y se vuelven y encogen sobre lo que podríamos llamar -siguiendo a Gaston Bachelard (1975) - esos "espacios de intimidad" de los protagonistas (la ciudad de pertenencia, la casa, el club social, el bar al que se va para reunirse con los amigos). En estas producciones fílmicas, esos territorios íntimos se van saturando de peajes
$11::$ Se han citado los escritos de Ernesto Laclau como armazón ideológico que dio respaldo teórico a las estrategias divisionistas del matrimonio, por cuanto una visión binaria de la política, acompañada por una agudización de conflictos en la comunidad, era, para este, el germen de una transformación social. Para más detalles, ver el análisis de Silvio Waisbord (2014). 
internos y exhiben una comunidad quebrada y una topografía fracturada que moldea las experiencias sociales, culturales y hasta medioambientales de su audiencia (Aitken y Zonn, 1994, p. 5).

Uno de los elementos más llamativos de la Argentina del período que va desde el default de 2001 hasta finales del período kirchnerista (2015) es la forma en que las geografías urbanas en particular van perdiendo su estatus como sitios de comunicación cultural y de interacción social espontánea. En muchas de ellas, ese espacio comunitario aparece sumido en el fracaso. En esa geografía común, ahora derruida y quebrada, se van consolidando compartimentos opresivos de exclusión permanente. Esta situación de deterioro de los lazos sociales resulta ser uno de los elementos que más recurrentemente se hace presente en el discurso cinematográfico argentino de esta época.

El caso de Juan José Campanella es un ejemplo notable de una filmografía que nos habla de pérdidas y fracasos que empujan a los protagonistas, como veremos de inmediato, a quedar entrampados en un recorrido circular por un paisaje nacional que empieza a cerrarse sobre sí mismo. Sin embargo, sus películas parecerían exhibir, por momentos, intentos por desembarazarse de esa tradición de pensamiento cultural que, en palabras de Shumway (1993, p. 12), ha encubierto una mitología de la exclusión, el disenso y el conflicto "antes que una idea nacional unificadora”.

\section{"Una sombra ya pronto serás"}

Las ruinas (y aquí usaré el término en su sentido más amplio) han sido consideradas tradicionalmente como sitio de memoria y contemplación (Mennel, 2008, p. 109). Citando a Susanne Marshall, Barbara Mennel anota que, si bien el tropo de la ruina se remonta a una tradición del arte barroco y román- tico, donde funcionó como alegoría, también podría interpretarse no tanto como una referencia histórica específica, sino como la señal del paso del tiempo en un nivel simbólico. De esta forma, redondea, esta idea podría funcionar como un elemento clave y paradójico para superar un momento histórico particular y serviría como detonante que le permitiría al discurso fílmico internarse en meditaciones metafísicas o morales.

En este sentido, me atrevería a decir que ese deambular circular de los protagonistas de nuestras películas por el espacio de la destrucción y la decadencia va construyendo un mapeo cognitivo que instituye un modo de reflexión cinematográfica del espacio comunitario. Este mapa cognitivo que se va formando ante la audiencia desencadenaría una meditación sobre su propio lugar en el mundo y marcaría ese instante en que se produce esa toma de conciencia de las causas de su condición de miseria, para terminar visibilizando su responsabilidad en su propio destino, como decía Camus más arriba.

Gran parte de la filmografía de Campanella está atravesada por los temas del deterioro y la derrota que, partiendo de la nostalgia, pero no quedándose en ella necesariamente, abren un momento de introspección en la memoria. Es esta una característica de un sujeto histórico que se niega a aceptar destinos prefijados de grandeza o condenas al éxito y a regodearse en una nostalgia paralizante. Por el contrario, comprende con sorpresa que la única salida de su ruina -que parece tan eterna como el castigo de Sísifo- consiste en afirmar su autonomía, tomar las riendas de su propia historia y convertirse en un miembro social que lucha por romper con los arquetipos del pasado y su repetición. En pocas palabras, se trataría de reflexionar sobre el terror y el peso que provoca la historia con el fin de romper la orgía repetitiva. Así 
ocurre con cada una de las películas de este director hasta la fecha, en donde el fracaso y un nuevo intento para superar la calamidad histórica van armando un recorrido común: Ni el tiro del final (también conocida como Loved Walked In, coproducción argentino-estadounidense de 1997), El mismo amor, la misma lluvia (1999), El hijo de la novia (2001), Luna de Avellaneda (2004), El secreto de sus ojos (2009) y Metegol (2013). ${ }^{12}$

El caso de esta última y la antepenúltima es paradigmático, por cuanto ambas parecen calcar, curiosamente, una misma historia. Y en efecto, así lo afirma el propio Campanella en ocasión del estreno de Metegol: "Metegol es emocionalmente Luna de Avellaneda para chicos” (reportaje en Scholz, 2013). No obstante, Eduardo Sacheri, coguionista de Metegol junto con Campanella, propone otra interpretación:

No es una película pensada "para chicos". Es una película pensada para que los chicos y los grandes se encuentren con una historia en la que habitan personajes a los que les suceden cosas. Es posible que las lecturas de los chicos y de los grandes difieran, al menos parcialmente. Pero creemos que la esencia de la película está en que encierra una historia. Una historia en la que viven personajes. Y, como viven, esos personajes enfrentan desafíos. Y cuando los enfrentan, necesariamente cambian. Creo que ése (sic) es uno de los grandes acuerdos narrativos que compartimos con Campanella (Sacheri, 2013, mi énfasis). ${ }^{13}$

Luna de Avellaneda cuenta las vicisitudes de un club social y deportivo barrial que corre el riesgo de sufrir una transformación importante (ser convertido en un casino) debido a unas deudas impagas. Román Maldonado (Ricardo Darín, actor preferido de Cam- panella) y sus amigos lucharán por la supervivencia del club, pero sin éxito. Los socios, en asamblea general, aprueban la venta del club a un consorcio anónimo representado por Alejandro (Daniel Fanego), un político profesional que llegó a rivalizar con Román por su esposa, Verónica (Silvia Kutika). Desilusionado, Román decide abandonar el país e irse a España junto con su familia. Sin embargo, en las vísperas de su viaje, al encontrar unos recuerdos de su infancia en una vieja maleta, se arrepiente y toma la decisión de quedarse en el barrio que lo vio nacer para seguir luchando.

Metegol, por su parte, es una película de animación que se inicia como relato enmarcado. ${ }^{14}$ Cuenta la historia de Amadeo y su relación conflictiva con su hijo Mati. Amadeo ha montado en un pequeño galpón detrás de su casa una reproducción a escala de un estadio de fútbol con unos jugadores de plomo que, agrupados en dos equipos (los rayados y los bordó), parecen tener vida solo delante de él. Su hijo no muestra demasiado interés en el pasatiempo de su padre y no parece "ver" la vida de los muñecos, atraído mucho más por los juegos electrónicos de su tableta. Una noche, ambos tienen un entredicho menor. A instancias de su esposa Laura, Amadeo se acerca a Mati y le narra cómo en su juventud logró salvar a su pueblo de las garras de Grosso, un jugador de fútbol presumido y rencoroso. Este se había empeñado en construir un estadio gigante y un parque de diversiones que terminaría con el pueblo y sepultaría el recuerdo de una derrota que había sufrido a manos de Amadeo en un juego de futbolín cuando eran niños.

En ambos productos se trata de películas que van construyendo una misma "metáfora cartográfica" (Gorelik, 2004, p. 266), en la que se cruzan "itinerarios, recorridos, relatos espaciales, espacio narrativo,
12:: Hacia marzo de 2019 (cuando fue preparado este texto), Campanella daba los toques finales a la remake de Los muchachos de antes no usaban arsénico, comedia negra de 1976, bajo la dirección de José Martínez Suárez. Con el sugerente título de El cuento de las comadrejas, contó con la participación de Graciela Borges, Luis Brandoni y Oscar Martínez, entre otros. El filme se estrenó en mayo de 2019 ("E regreso triunfal...", 2018).

13:: Pese a estas diferencias sutiles de opinión, es evidente que los temas y algunos personajes de ambas películas se entrelazan de manera significativa. Vale la pena destacar aqui que el guion de Metegol fue inspirado por un muy breve relato de "Memorias de un wing derecho" de Roberto Fontanarrosa (1996).

14:: Para este análisis he seguido la versión argentina del filme. Existen dos versiones más: una hispanoamericana (doblada por actores mexicanos), con el título original; y otra con acento español peninsular, titulada Futbolin ("Hasta tres versiones...", 2013). 


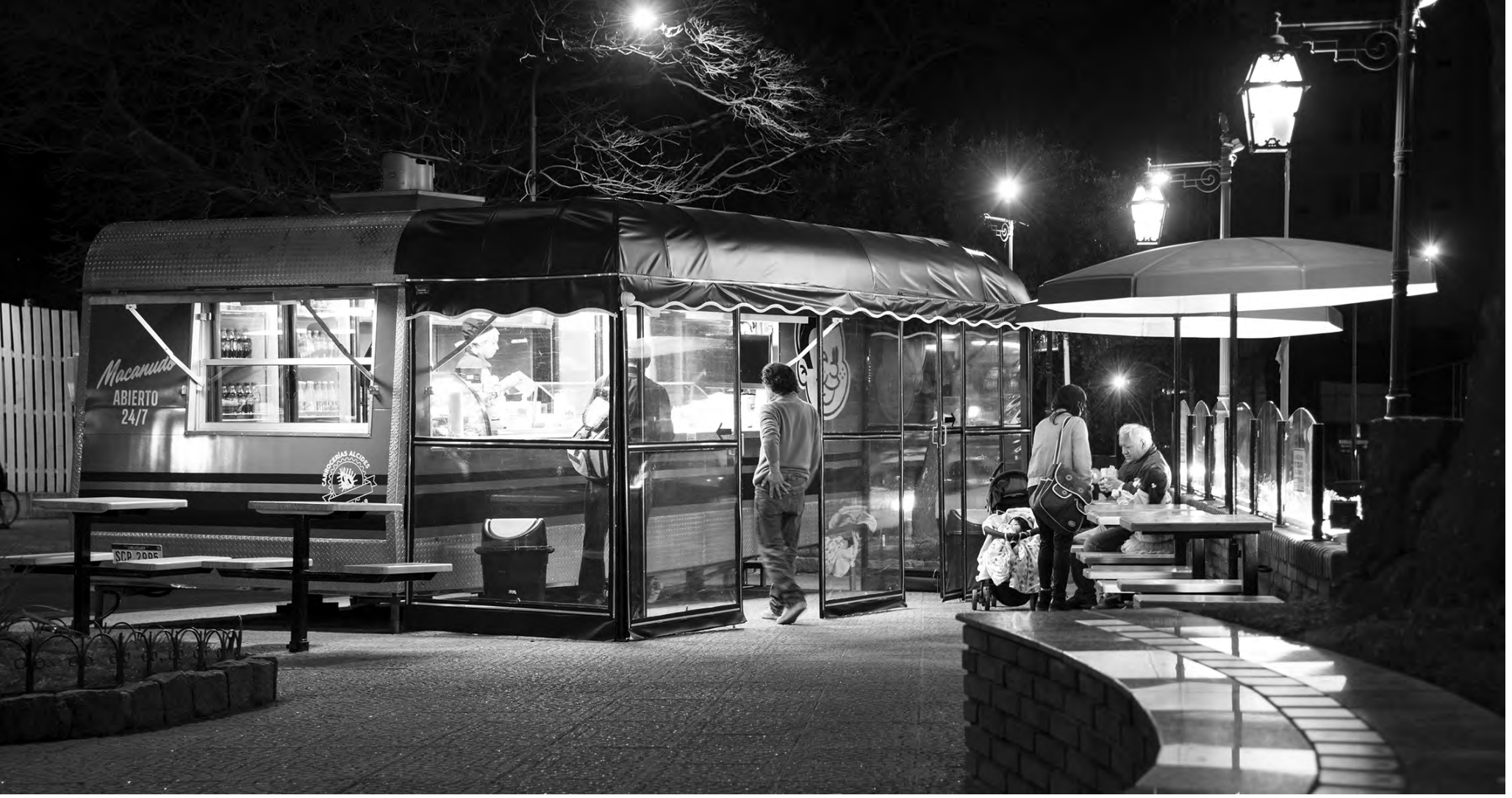

Foto: Ignacio Sánchez

15:: Ese pueblo de Metegol, identificado como "muy muy cercano", evoca la ciudad hollywoodense de "Muy Muy Lejano", de la película Shrek. Otro guiño nostálgico dirigido a una audiencia adulta- es el aspecto

físico de algunos de los muñecos del futbolín, cuya fisonomía recuerda a algunos de los jugadores del seleccionado argentino de fútbol de 1978. En estos detalles sutiles

se nota el perfil que Campanella imagina de sus propios espectadores

y el conocimiento compartido que asume que tienen. mapas cognitivos, territorialidades, fronteras". Ambas se inician en principio con una visión cenital: el pueblo sin nombre de Metegol, por un lado; y la perspectiva aérea del club Luna de Avellaneda, con su fiesta popular, en esa noche especial de carnaval en la que nacerá Román, por otro. Pero pronto en las dos se baja a ras del suelo, para encontrarse con los que, en palabras de Gorelik (citando a De Certeau en su análisis de El tercer hombre de Orson Welles), serían

los practicantes ordinarios de la ciudad, los caminantes, y participar del múltiple texto urbano que ellos escriben sin poder ver, para redescubrir que, bajo los discursos que los ideologizan, proliferan los ardides y las tácticas, "los procedimientos multiformes, resistentes, astutos y pertinaces" que escapan al control panóptico en una "ilegitimidad proliferante" (Gorelik, 2004, p. 268).

Junto a esta visión idealizada de un ayer familiar de valores fundamentales ("Esto ocurrió hace muy poco tiempo, en un pueblo muy muy cercano, donde había una plaza, como la nuestra, la estatua de un fundador, como los nuestros, y también había un bar como el nuestro", empieza Amadeo en el relato que le cuenta a su hijo), se hace presente una voz desmesurada en ese pasado, que inunda y ensordece todo diálogo: la del cantante Alberto Castillo y los versos de "Así se baila el tango", en la primera; y la de un José María Muñoz, famoso relator deportivo del mundial de fútbol de 1978, que parece comentar en off los avatares del juego de futbolín en el que Amadeo se entretiene con su "noviecita de la infancia", en la segunda. ${ }^{15}$

Así, a partir de un juego emotivo, se lleva a la audiencia a rememorar esas voces icónicas y a identificarlas con momentos especiales de un pasado idílico. Este, en una lectura apresurada, parecería caracterizarse por un estado de "ingenuidad inicial". Nótese que, en ambos casos, se alude a los primeros años de los protagonistas: el nacimiento de Román en Luna de Avellaneda y la niñez de Amadeo en Metegol, inmersos en una especie de locus amoenus comunitario. Es este un espacio que, se sugiere, se ha ido escurriendo y disgregando en un presente que avanza en forma veloz (como veloz es la transición de imágenes que nos presenta a los personajes ya en su adultez).

Desde esta perspectiva, las dos películas comienzan con una actitud que bordea una nostalgia que podría parecer paralizante a primera vista: esa especie de lugar idealizado, seguro y tranquilo de la infancia. No obstante, en mi opinión, no estamos ante una experiencia visual que inmoviliza, sino ante una meditación activa, que pone en foco el nudo del problema comunitario y que va 
mucho más allá de un simple juego con la añoranza y la melancolía por "un pasado feliz". En efecto, se podría decir que los personajes de Campanella, inmersos en un presente alienante, realizan operaciones precartográficas, esto es, solo el viaje a través de ese espacio urbano en ruinas les permitiría ver, en perspectiva, sus reales condiciones de existencia.

En este punto, vale la pena destacar que diversos estudios han asociado la nostalgia con políticas reaccionarias, porque evocan un pasado mediante emociones sentimentales que, si bien no llegan a presentarlo como perfecto, al menos resulta mejor que el presente (Davis, 1977; Smith, 2000; Pickering y Keightley, 2006). Sin embargo, sabemos que se rechaza esta forma en el arte por considerarla un acto inútil e irrelevante (Lowenthal, 2015, pp. 49-54; y Kenny, 2017). Esto es lo que Svetlana Boym (2001, p. 42) llamaría una "nostalgia restauradora", característica de ciertos nacionalismos populistas que difunden teorías conspirativas, tramas maniqueas y mitos históricos a medida, como veíamos más arriba.

Otras perspectivas (la misma Boym, 2001; Legg, 2005; Cashman, 2006; Smith, 2006; Smith y Campbell 2017; Loveday, 2014) ven en ella, por otro lado, un ingrediente reflexivo y, en consecuencia, mucho más productivo, por cuanto aborda positivamente el trauma comunitario con su historia y reconoce la imposibilidad de reconstruir ese pasado, aun cuando parece recrearse "sobre las ruinas, la pátina del tiempo y de la historia, en los sueños de otro lugar y otro tiempo"16 (Boym, 2001, p. 42). La nostalgia reflexiva entrañaría así un análisis crítico de la historia y la memoria de la comunidad, pero no se propondría reconstruir su pasado. Por el contrario, apuntaría a abrir perspectivas ambivalentes y potencialmente críticas sobre las creencias y valores del presente, y entenderlo, evaluarlo y valorarlo a contraluz del pasado. Esta nostalgia reflexiva, al decir de Boym, puede ser irónica y humorística, como efectivamente ocurre en estos dos filmes que menciono -aunque esto atraviesa toda la filmografía de Campanella-. El tratamiento de esta nostalgia revela "que el anhelo y el pensamiento crítico no se oponen entre sí, ya que los recuerdos afectivos no absuelven a nadie de la compasión, el juicio o la reflexión crítica" (Boym, 2001, p. 50).

Después de haber empujado la piedra metafórica de su herencia histórica, hecho ese mapeo cognitivo de su terruño, y llegado a los restos materiales de su pasado (el carné de socio vitalicio del club o el reencuentro con los viejos muñecos de su antiguo metegol de la infancia), ambos protagonistas -Román y Amadeo respectivamente- logran abrir ante sí, como en una caja de Pandora, los múltiples planos de conciencia que estaban dormidos. Ese es el momento de la anagnórisis campanelliana, por la cual se les revela a los personajes una idea más exacta de sí mismos, de su entorno y de su posible futuro.

Se dan cuenta entonces de la imposibilidad de reconstruir de las cenizas aquel lugar mítico (llámese club o pueblo, formas alegóricas de la nación a las que estos espacios hacen referencia). Se les presenta la oportunidad única de desenamorarse del hechizo del pasado que, como a Sísifo, los empuja a regresar con la piedra, una y otra vez por el mismo camino. Liberados del yugo de esa piedra, quedarían en condiciones ahora de enterrarla para siempre y erigir un nuevo espacio que deje atrás, en forma definitiva, los castigos eternos de dioses inexistentes. Pero nótese lo interesante: se funda un nuevo club o un nuevo pueblo (o como en El hijo de la novia, un nuevo restaurante) al lado del anterior porque, como observa Boym (2001):

La nostalgia reflexiva no pretende reconstruir el mítico lugar llamado hogar; está "enamorado de la distancia, no del referente mismo”. Este tipo de narrativa nostálgica es irónica, inconclusa y
16:: Todas las citas de Boym presentes en este articulo fueron traducidas. 
fragmentaria. Los nostálgicos del segundo tipo son conscientes de la brecha entre la identidad y el parecido; la casa está en ruinas o, por el contrario, acaba de ser renovada y gentrificada hasta el punto de ser irreconocible. Esta desfamiliarización y el sentido de la distancia los lleva a contar su historia, a narrar la relación entre el pasado, el presente y el futuro. A través de este anhelo, estos nostálgicos descubren que el pasado no es solo lo que ya no existe, sino que, citando a Henri Bergson, el pasado "puede actuar y actuará insertándose en una sensación presente de la que toma prestada la vitalidad". El pasado no se hace a imagen del presente ni se ve como un presagio de algún desastre presente; más bien, el pasado abre una multitud de potencialidades, de posibilidades no teleológicas de desarrollo histórico. No necesitamos una computadora para acceder a las virtualidades de nuestra imaginación: la nostalgia reflexiva tiene la capacidad de despertar múltiples planos de conciencia (p. 51) [Cursivas añadidas].

En este sentido, la nostalgia por el lugar perdido de estas dos películas, como otras de Campanella mencionadas, se instala en ese espacio ambiguo de medi(t) ación. Pasajes, recorridos y viajes por las ruinas de la propia geografía empujan al protagonista $-\mathrm{y}$ con él, a la audiencia- a enfrentarse con una realidad evidente que no se había querido reconocer o ver: el obstinado atavismo de una mentalidad polarizante que ha inundado el espacio común de convivencia con contradicciones y conflictos irresueltos. Las ruinas de la ciudad evocan, a manera de eco, la historia inmediata del espacio comunitario, con sus desavenencias y desencuentros, y permiten negociar cuestiones que hacen a una convivencia civilizada y conciliatoria.

Así, por ejemplo, resultan significativas, en Luna de Avellaneda, las imágenes de zonas industriales abandonadas de la ciudad por las que dan vuelta los personajes sin rumbo fijo. Estos espacios de la devastación están ahora convertidos en conglomerados de galpones cerrados, en cuyas paredes se lee, con sorna, algún grafiti con un mensaje de Teresa de Calcuta que apela al compromiso, al esfuerzo y al vínculo ("Para amar, servir"), ironía que Koza (2004, p. 77) no logra percibir en su crítica feroz a la película. En ese paisaje se producirá el abrazo de reconciliación de Román con su esposa, después de la votación que lo había despojado de su club. Ese territorio urbano en ruinas es, por lo tanto, el lugar no solo de la decadencia, en donde se exhibe el presente más descarnado, sino también de sanación, por cuanto gracias a la percepción y aprehensión de sus alrededores inmediatos (esto es, de su propia historia) se estará en condiciones de encontrar su propia situación en el mundo. ${ }^{17}$

El discurso fílmico campanelliano visualiza esa pugna discursiva a lo largo de toda su producción. Al fin de cuentas, la mayor parte de sus películas - de una forma $\mathrm{u}$ otra - cuentan la misma historia una y otra vez y exhiben didácticamente los modos y medios particulares con los que operan los relatos maniqueos que circulan en su sociedad "y a través de los cuales las comunidades lingüística y simbólicamente mediadas se forman y disuelven" (Bell, 2003, p. 69).

\section{Abismarse en la reflexión}

Como hemos visto, en el diálogo que ambas películas establecen entre sí, y en relación con la filmografía de Campanella y con el propio contexto político de producción, se va conformando una construcción en espejo. En ella la audiencia se abisma en esa peculiar mentalidad binaria de las relaciones sociales que se ha dado hasta el paroxismo en su historia y que se exacerbó aún más en el contexto de producción de los filmes (que coincidió con el comienzo y el fin de la administración neopopulista del kirchnerismo). En este sentido, ambas películas coinciden con un período histórico marcado por un tipo de nostalgia restaurativa antinómica que, desde las máximas ins- 
tituciones de poder, se intentaba erigir como "política de la memoria" institucional (véanse en este punto los estudios de Montero 2007a, 2007b, 2008, 2009a, 2009b; Montero y Vincent 2013). Y si bien Luna de Avellaneda es de 2004 y la crítica ha visto referencias a las consecuencias del período menemista y "al lenguaje de las asambleas populares tras el estallido de diciembre de 2001" (Andermann, 2015, p. 88), en su historia ya parece anticiparse el surgimiento de las ideas del kirchnerismo. Al fin de cuentas, como señala Frank (1991, p.58), los artistas son siempre los barómetros más sensibles del cambio cultural y son los primeros en registrar para la sociedad que consume su trabajo ciertas tendencias latentes en ella.

Ambos filmes, así, parecen instaurar un debate con esta forma y se juegan por una lectura nostálgica reflexiva. En efecto, les ofrecen a sus espectadores la posibilidad de visualizar, simbólicamente, un escenario posible de superación de esas viejas visiones arcaicas de las que nos hablaba Katz más arriba. Por grandes que sean esos enfrentamientos, al fin de cuentas, todavía queda lugar para poder resolverlos, paradójicamente, dentro del marco de los viejos relatos clásicos, pero sin matar al ogro, sino tomando distancia de él (sea este Grosso -en Metegol-, Alejandro o el grupo que este representa -en Luna de Avellaneda-). Se propone la idea de construir un nuevo club o un nuevo pueblo, pero sin los lastres de ese pasado antinómico. En este sentido, es por demás reveladora la escena en que Grosso queda solo, aislado y cubierto por su propia bandera (como ocurre en la escena final del partido que juega con Amadeo).

“¿Cómo se hace un club nuevo?”, le pregunta Román a su amigo Amadeo (Eduardo Blanco). Y de inmediato echan a correr los títulos finales, mientras los acordes de "Siga el baile", cantados por Alberto Castillo otra vez, inundan la pantalla, alentando a la no rendición. ¿Cómo se hace un pueblo nuevo?, parece a su vez interrogarse el Amadeo de Metegol al final de su relato, cuando le explica a su hijo que todos decidieron recomenzar la lucha. No obstante, para esto, debieron abandonar el lugar original en el que vivían -cruzado también por un pensamiento binario- y conformaron uno nuevo en otro sitio, pero dejando al margen las diferencias:

\section{Mati: ¿Y qué pasó?}

Amadeo: Y los habitantes prefirieron fundar un pueblo nuevo antes de que vivir en el [enfatiza] del Grosso.

Mati: ¿Y qué pasó con Amadeo?

Grosso: Él solo quería ser el ídolo de Laurita. Así que se casaron y tuvieron un hijo. Un hijo hermoso...

Mati: Ah, no te creo nada. ¡Jugadores de metegol...! ¿Quién va a creer eso?

Amadeo: Yo te conté la historia real. Si vos querés creer o no, ... cosa tuya.

Mati: ¿En serio existen esos jugadores? ¿Están vivos? ¡Oh, papá! ¿Los puedo ver? Amadeo: ¡Creer para ver! [Cursivas añadidas]

Y con la inversión de ese cliché lingüístico final -transformado ahora en cuestión de fe-, Amadeo se retira lentamente del dormitorio. Su hijo, que ha quedado reflexionando (y con él, la audiencia), ve a través de la ventana la luz en la puerta del galpón en donde se ha refugiado su padre y decide ir detrás de él. Por primera vez, logra distinguir aquello que no había visto antes y que había estado delante de sus ojos: los muñecos con vida propia, mientras juegan "un partido amistoso". Algo parecido le ocurrirá a Román en Luna de Avellaneda cuando, accidentalmente, desparrama los viejos recuerdos de su infancia en el garaje de su casa. Unas fichas de dominó infantil, autitos, un viejo vagón de tren, y su viejo carné de socio vitalicio son el detonante que le permiten creer que un nuevo club es posible si se logran rearmar esos ladrillos -esos recuerdos, esas experiencias- de una manera diferente. Solo hay que dejar de lado las viejas divisiones del pasado, parecen sugerir ambas escenas, porque únicamente han sabido producir territorios estériles. 
18:: Estas declaraciones fueron consideradas peligrosas por la candidata Margarita

Stolbizer, de la Alianza Progresistas (alianza de centroizquierda conformada por el Partido Socialista, el Partido Socialista Auténtico, el Movimiento Libres del Sur, el Partido Generación para un Encuentro Nacional y el Movimiento Polo Social), por quien Campanella había mostrado intención de voto unos meses antes. El director fue muy criticado en las redes y en notas periodisticas por estas expresiones y por sus llamativos cambios de simpatías políticas (véase Spillman, 2015).
Así, tanto Luna de Avellaneda como Metegol se cierran con una especie de "renacimiento de la fe a partir de las cenizas” para levantar una nueva geografía -simbolizada en la figura de un club o de un nuevo pueblo (Andermann, 2015, p. 85)-. En este sentido, nótese el cambio que proponen las palabras finales de Metegol y que, de alguna manera, se presuponen en el final de Luna con el candombe de Castillo. Ya no se trata de "ver para creer" sino de "creer para ver", esto es, creer en la posibilidad de la imaginación como instrumento disparador para seguir adelante y crear una nueva geografía en donde se dejen de lado las grietas inútiles o los restos del pasado, porque al final, como les dice "el Loco" a Capi y su rival, al ver la devastación en la que ha quedado reducido el juego de metegol: "Miren a su alrededor. ¿No se dan cuenta de que lo que nos une es mucho más de lo que nos separa? Desde ahora vamos a trabajar juntos".

Se trata, en definitiva, de una postura orientada hacia el futuro, que pone ante la audiencia una nostalgia por un porvenir que ella misma podría tener si no se hubiera enredado en los meandros de una historia cíclica. Como muy atinadamente concluye Boym, respecto de la nostalgia,

La nostalgia creativa revela las fantasías de la época, y es en esas fantasías y potencialidades que nace el futuro. Uno se siente nostálgico no por el pasado como era, sino por el pasado como podría haber sido. Es este pasado perfecto el que uno se esfuerza por realizar en el futuro (Boym, 2001, p. 353).

La ambivalencia, la complejidad de la historia y la especificidad de las circunstancias modernas se exhiben en pantalla, cuestionando las antiguas profecias de grandeza con una mirada crítica de aquellos mitos, al tiempo que hace "memoria del futuro". Y así como Luna de Avellaneda pronosticaba - sin saberlo todavía- el surgimiento del kirchnerismo, Metegol presagia la formación de la coalición de partidos que, en 2015, bajo el sugestivo nombre de Cambiemos, ganaría en las elecciones presidenciales de ese año. En este sentido, son significativas las palabras de apoyo que dio Campanella por esos meses a la nueva coalición: "Solo hay dos melodías: kirchnerismo y Cambiemos. Todo lo demás es ruido. Votá en primera (vuelta) como si fuera ballotage, o puede no haberlo" (Bermúdez, 2015). ${ }^{18}$ Es verdad que, leídas a la distancia, las palabras de Campanella podrían parecer contradictorias con lo que expresaba en su discurso fílmico. No obstante, considero que Campanella veía en el surgimiento de la nueva fuerza política una superación de la dicotomía que el kirchnerismo había exaltado y encarnado durante sus 12 años de gobierno.

En suma, esta nostalgia reflexiva hace sus mementos, esto es, se detiene a discurrir con atención y a trazar un viaje introspectivo por las tradiciones argentinas para poder entender las formas en que ellas han nutrido $\mathrm{y}$ problematizado el presente. Pero en este recorrido se descubre que estas tradiciones no hablan más que de discontinuidades. El discurso cinematográfico de Campanella expone así cómo esta herencia ininterrumpida de anomalías que llega hasta el presente desde el pasado se recompone una y otra vez, en un ciclo de eterno retorno que, a todas luces, ha resultado improductivo.

\section{Conclusiones}

Siguiendo a Iain Chambers y su lectura de Benjamin (1994, p. 102), la Historia (así con mayúscula) se haría presente en la realidad en forma de ruina, como "atracción a la autodestrucción”. En otras palabras, ambas películas se proponen una exposición y comprensión de la tradición del pensamiento cultural argentino, poniendo en cuestionamiento que cualquier identificación obvia con un sentido unitario de pertenencia comunitario se ha ido dispersando hasta dejar cáscaras vacías. Y esto se podría extender a todo el cine de Campanella, quien, paradójicamente, vuelve una y otra vez sobre esto como el gran tema de su discurso fílmico. 
Este viaje interno le permitiría al director pasar de la fe en una "comunidad imaginada" al reconocimiento de formar parte de identidades complejas, forjadas en historias discontinuas, heterogéneas, contradictorias y, sobre todo, redundantes. En fin, esta nostalgia reflexiva muestra, como en un espejo, un mundo azaroso, en donde las tradiciones y las raíces se vuelven inestables, al punto de que se hace necesario reescribirlas y modificarlas para conformar un paisaje más efectivo que, de una buena vez, permita mirar hacia el futuro con mayor convicción.

En definitiva, no se trata entonces de restaurar un supuesto pasado perfecto que resulte mejor que el presente. Como señala Chambers en el epígrafe que abre este documento, no se puede volver atrás, porque ese pasado solo ha quedado como huella en la memoria. Solo se puede ejecutar, siempre a través de una mirada crítica, un viaje por historias y relatos que le permitan a la audiencia posicionarse, inscribirse y ubicarse en su presente para lanzarse hacia el futuro, como lo ha señalado el propio director en algunas entrevistas ("Juan José Campanella: Es una falla...”). Para Campanella, el Sísifo argentino solo tiene una opción: abandonar el castigo de unos dioses inexistentes y lanzarse a recuperar el tiempo perdido, porque su destino no está encadenado a ninguna roca y solo le pertenece a él, inmerso como está, en su hic et nunc.

\section{Referencias}

Aitken, S., y Zonn, L. E. (1994). Re-presenting the place pastiche. En S. Aitken y L. E. Zonn (Eds.), Place, Power, Situation, and Spectacle: A Geography of Film (pp. 3-24). Lanham, MD: Rowman \& Littlefield.

Altamirano, C. (2008). Pasado, presente. En C. Lida, H. Crespo y P. Yankelevich (Eds.), Argentina, 1976. Estudios en torno al golpe de estado (pp. 17-33). Buenos Aires, Argentina: Fondo de Cultura Económica.

Andermann, J. (2015). Nuevo cine argentino. Buenos Aires, Argentina: Paidós.

Anderson, B. (2007). Comunidades imaginadas. Reflexiones sobre el origen y la difusión del nacionalismo. Ciudad de México, México: Fondo de Cultura Económica.

Andriotti Romanin, E. (2011). Nosotros los del 73. Memoria y política en la Argentina post-2011. Nómadas. Revista Crítica de Ciencias Sociales y Jurídicas, Núm. Especial: América Latina, 197-212.

Aprea, G. (2008). Cine y políticas en Argentina: continuidades y discontinuidades en 25 años de democracia. Buenos Aires, Argentina: Universidad Nacional de General Sarmiento.

Arendt, H. (1998). La condición humana. Barcelona, España: Paidós. Bachelard, G. (1991). La poética del espacio. Ciudad de México, México: Fondo de Cultura Económica.

Balandier, G. (1994). El poder en escenas. De la representación del poder al poder de la representación. Buenos Aires, Argentina: Paidós.

Barbosa, S. (2010). Menemismo y kirchnerismo en Argentina: un análisis político discursivo de su construcción hegemónica. Pensamento plural, 06, 11-34.

Bauman, Z. (2001). En busca de la política. Buenos Aires, Argentina: Fondo de Cultura Económica.

Bauman, Z. (2004). Modernidad líquida. Buenos Aires, Argentina: Fondo de Cultura Económica.

Bauman, Z. (2008). La sociedad sitiada. Buenos Aires, Argentina: Fondo de Cultura Económica.

Bauman, Z. (2009). Comunidad. En busca de seguridad en un mundo hostil. Madrid, España: Siglo XXI.

Bell, D. (2003). Mythscapes: Memory, Mythology, and National Identity. British Journal of Sociology, 54(1), 63-81.

Bermúdez, G. (2015, 14 de octubre). Elecciones 2015. La pelea por el voto útil: Campanella lo apoyó a Macri y Stolbizer se enojó. Clarín. Recuperado de https://www.clarin.com/politica/ elecciones_2015-margarita_stolbizer-juan_jose_campaneIla_0_BJg3ZKv7x.html

Boym, S. (2001). The Future of Nostalgia. New York, NY: Basic Books.

Camus, A. (1995). El mito de Sísifo. Madrid, España: Alianza.

Capano, D. C. (2017). Identidad nacional y valores comunitarios en El hijo de la novia (2001) y Luna de Avellaneda (2004). Imagofagia. Revista de la Asociación Argentina de Estudios de Cine yAudiovisual, 15, 1-28. Recuperado de http://asaeca.org/ imagofagia/index.php/imagofagia/article/view/1305 
Cashman, R. (2006). Critical Nostalgia and Material Culture in Northern Ireland. Journal of American Folklore, 119(427), 137-160.

Chambers, I. (1994). Migrancy, Culture and Identity. Londres, Reino Unido: Routledge.

Cohen, A. (2001). The Symbolic Construction of Community. Londres, Reino Unido: Routledge.

Dain, A., y Barros, M. (2011, 24-26 de agosto). El kirchnerismo y la desmesura de lo político. Ponencia presentada en $V$ Coloquio de investigadores en estudios del discurso. II Jornadas internacionales de discurso e interdisciplina. Universidad Nacional de Villa María, Córdoba, Argentina. Recuperado de http://www.academia.edu/2033558/El_kirchnerismo_y_la_desmesura_de_lo_pol\%C3\%ADtico

Davis, F. (1977). Nostalgia, Identity, and the Current Nostalgia Wave. The Journal of Popular Culture, 11(2), 414-424.

Dillon, A. (2015). La crisis argentina en el cine de Juan José Campanella. El ojo que piensa. Revista virtual de cine iberoamericano, 6(11), 1-33. Recuperado de http://www.elojoquepiensa.cucsh. udg.mx/index.php/elojoquepiensa/article/view/207

Domínguez, J. M. (2013, 25 de octubre). La grieta existe desde que llegaron los españoles. Reportaje a Diego Peretti. Diario Perfil. Recuperado de http://www.perfil.com/espectaculos/La-grieta-existe-desde-que-Ilegaron-los-espaoles-20131025-0047.html

El regreso triunfal de Campanella promete mucho. (2018, 21 de julio). La Nueva. Recuperado de https://www.pressreader. com/argentina/la-nueva/20180721/281500752037826

Feinmann, J. (1995). La sangre derramada. Ensayo sobre la violencia política. Buenos Aires, Argentina: Ariel.

Fernández Pedemonte, D. (2006). De la Rúa, Kirchner y las prerrogativas del discurso del poder. En L. Elizalde, D. Fernández Pedemonte y M. Riorda (Eds.), La construcción del consenso. Gestión de la comunicación gubernamental (pp. 269-78). Buenos Aires, Argentina: La Crujía.

Fontanarrosa, R. (1996). "Memorias de un wing derecho". En R. Fontanarrosa, El mundo ha vivido equivocado y otros cuentos (pp. 45-47). Buenos Aires, Argentina: Ediciones de la Flor.

Frank, J. (1991). The Idea of Spatial Form. New Brunswick, NJ: Rutgers UP
Garcia Canclini, N. (2011). La sociedad sin relato. Antropología y estética de la inminencia. Ciudad de México, México: Katz.

Gorelik, A. (2004). Miradas sobre Buenos Aires. Historia cultural y crítica urbana. Buenos Aires, Argentina: Siglo XXI.

Graves, R. (1985). Los mitos griegos. Buenos Aires, Argentina: Hyspamérica.

Hasta tres versiones del español para Metegol/Futbolín en su carrera internacional. (2013, 14 de noviembre). Noticine. Recuperado de https://www.imdb.com/news/ni56427429

Juan José Campanella: Es una falla caer en la nostalgia. (2015, 31 de mayo). La Capital. Recuperado de https://www.lacapital. com.ar/edicion-impresa/juan-jose-campanella-es-una-faIla-caer-la-nostalgia-n654065.html

Katz, A. (2013). El simulacro. Por qué el kirchnerismo es reaccionario. Buenos Aires, Argentina: Planeta.

Kenny, M. (2017). Back to the populist future?: understanding nostalgia in contemporary ideological discourse. Journal of Political Ideologies, 22(3), 256-273.

Korstanje, M. (2011). El culto K en la era contemporánea. Crónica, génesis y apoteosis del proceso kirchnerista. Nómadas. Revista Crítica de Ciencias Sociales y Jurídicas, Número especial: América Latina, 233-268.

Koza, R. A. (2004). Con los ojos abiertos: crítica cinematográfica de algunas películas recientes. Córdoba, Argentina: Editorial Brujas.

Lanata, J. (2013, 10 de agosto). La grieta. Clarín. Recuperado de http://www.clarin.com/opinion/Grieta_0_971902892.html

Legg, S. (2005). Contesting and Surviving Memory: Space, Nation and Nostalgia in Les Lieux de Mémoire. Environment and Planning D: Society and Space, 481-504.

Loveday, V. (2014). "Flat-capping It": Memory, Nostalgia and Value in Retroactive Male Working-class Identification. European Journal of Cultural Studies, 17(6), 721-735.

Lowenthal, D. (2015). The Past is a Foreign Country. Cambridge, Reino Unido: Cambridge UP.

Lusnich, A. L. (Ed.). (2005). Civilización y barbarie en el cine argentino y latinoamericano. Buenos Aires, Argentina: Biblos.

Mennel, B. (2008). Cities and Cinema. New York, NY: Routledge.

Mitchell, W. J. T. (1980). Spatial Form in Literature: Toward a General Theory. Critical Inquiry, 6(3), 539-567. 
Montero, A. S. (2007a, 19-21 de setiembre). Memorias discursivas de los '70 y ethos militante en la retórica kirchnerista (2003-2006). IV Jornadas de jóvenes investigadores. Facultad de Ciencias Sociales. Mesa: Política, discurso e ideología. Instituto Gino Germani (UBA). Recuperado de http:// webiigg.sociales.uba.ar/iigg/jovenes_investigadores/4jornadasjovenes/EJES/Eje\%205\%20Politica\%20ldeologia\%20 Discurso/Ponencias/MONTERO\%20Ana\%20Soledad.pdf

Montero, A. S. (2007b). Política y convicción. Memorias discursivas de la militancia setentista. Revista latinoamericana de estudios del discurso, 7(2), 91-114.

Montero, A. S. (2008). Justicia y decisión en el discurso presidencial argentino sobre la memoria (2003-2007). Confines, 4(7), 27-41.

Montero, A. S. (2009a). Puesta en escena, destinación y contradestinación en el discurso kirchnerista (Argentina, 2003-2007). Discurso y sociedad, 3(2), 316-47.

Montero, A. S. (2009b, 16-18 de abril). Democracia y desmesura. Un análisis polifónico-argumentativo del discurso kirchnerista. Actas del IV Coloquio de la Asociación Latinoamericana de Estudios del Discurso. Universidad Nacional de Córdoba. Recuperado de http://www.lenguas.unc.edu.ar/aledar/hosted/ actas2009/expositores/Montero,\%20Ana\% 20Soledad.pdf

Montero, A. S., y Vincent, L. (2013). Del "peronismo impuro" al "kirchnerismo puro": la construcción de una nueva identidad política durante la presidencia de Néstor Kircher en Argentina (2003-2007). Postdata, 18(1), 123-157.

Neyret, J. P. (2004). "Soy un perro de la calle". Entrevista con Nicolás Shumway. Espéculo. Revista de estudios literarios, 26. Recuperado de https://webs.ucm.es/info/especulo/numero26/ shumway.htmIRed

Pasquini Durán, J. M. (1995). Ilusiones argentinas. Un relato de ideas. Buenos Aires, Argentina: Planeta.

Pickering, M., y Keightley, E. (2006). The Modalities of Nostalgia. Current Sociology, 54(6), 919-941.

Rancière, J. (2007). En los bordes de lo político. Buenos Aires, Argentina: La Cebra.

Sacheri, E. (2013, 13 de julio). Metegol: Una historia en la que viven personajes. Perfil. Recuperado de https://www.pressreader. com/argentina/perfil-sabado/20130713/283085591783848

Sarlo, B. (2011). La audacia y el cálculo. Kirchner 2003-2010. Buenos Aires, Argentina: Sudamericana.
Scheines, G. (1992). Las metáforas del fracaso. Desencuentros y utopias en la cultura argentina. Buenos Aires, Argentina: Sudamericana.

Schmidt, S. (2012). Historias de la debacle y la migración en el imaginario fílmico argentino-español. Amérique Latine Histoire et Mémoire. Les Cahiers ALHIM, 23. Recuperado de http://journals.openedition.org/alhim/4183

Scholz, P. (2013, 7 de julio). Campanella: "Quiero que Metegol sea la película que más gente llevó en la historia del cine en la Argentina" (Entrevista al director). Clarín. Recuperado de https://www.clarin.com/espectaculos/quiero-metegol-pelicula-historia-argentina_0_SyqHvOUsPQg.html

Sennett, R. (1978). El declive del hombre público. Barcelona, España: Península

Sennett, R. (2012). Together: The Rituals, Pleasures, and Politics of Cooperation. New Haven, CT: Yale UP.

Shumway, N. (1993). La invención de la Argentina. Historia de una idea. Buenos Aires, Argentina: Emecé.

Smith, K. (2000). Mere Nostalgia: Notes on a Progressive Paratheory. Rhetoric \& Public Affairs, 3(4), 505-527.

Smith, L. (2006). Uses of Heritage. Londres, Reino Unido: Routledge.

Smith, L., y Campbell, G. (2017). "Nostalgia for the Future": Memory, Nostalgia and the Politics of Class. International Journal of Heritage Studies, 23(7), 612-627.

Spillman, E. (2015, 19 de marzo). Campanella apoya a Cambiemos: polémica por su "voto celebrity". Perfil. Recuperado de https://www.pressreader.com/argentina/perfil-sabado/20151017/281509340029252

Telefé. (2013, 7 de agosto). Programa periodístico en TV:Periodismo para todos - Martín Fierro 2013 [Archivo de vídeo]. Recuperado de https://www.youtube.com/watch?v=fCwNwipAdoc

Waisbord, S. (2014). Vox populista. Medios, periodismo, democracia. Barcelona, España: Gedisa.

Filmes

Campanella, J. J. (Director). (2004). Luna de Avellaneda [Película]. Argentina, España: 100 Bares Producciones, Pol-Ka Producciones, JEMPSA y Tornasol Films.

Campanella, J. J. (Director). (2013). Metegol [Película]. Argentina, España: 100 Bares Producciones, Catmandu Entertainment, Antena 3 y JEMPSA. 